\title{
OUR SURGICAL APPROACH TOWARDS THE TREATMENT OF URETHROCELE AND URETHRAL FISTULA
}

\author{
F. Jurascheck, ${ }^{1}$ P. Dollfus, A. Notter, C. Moustafa, A. Mennecier and G. Adli \\ Service d'Urologie, Centre Hospitalier, 6805I Mulhouse, France
}

\begin{abstract}
A new technique, described in the text, has been elaborated inspired by that of Monseur (1968) for urethral techniques. It has been performed with success in three paraplegics and in one incomplete tetraparesis. The plastic reconstruction of the diseased part of the urethra after excision of the stenosis and a fistula or diverticula by rotation and fixation to the subcavernal groove creates, in fact, an enlarged neo-urethra rendering the recurrence of the primary lesion practically impossible. This technique, first applied to spinal cord injuries, has been extended with permanent success to other lesions, such as tuberculosis stenosis and malformations.
\end{abstract}

Key words: Spinal cord injury; Urethral fistula; Urethral diverticulum; Urethral stenosis.

\section{Introduction}

THE incidence, caused mainly by improper management of the indwelling catheter, of multiple stenosis, diverticulae and fistula of the urethra has diminished dramatically in the past years. Different techniques have been reviewed and evaluated by Walsh (1964), Bors and Comarr (I97I) and Guttmann (1976). Nowadays, proper bladder and sphincter management has been codified especially in the acute phase, mainly since the introduction of intermittent catheterisation. These urethral complications, in patients with a particularly lessened healing capability below the level of the spinal cord lesion, besides causing a severe obstruction to the urinary flow and recurrent urinary infections, can be the cause of severe autonomic dysreflexia.

The surgical cure of these abnormalities has been in the past very hazardous, either because of immediate postoperative recurrence, or in the following months or years. Reasonable abstention has been nowadays advocated by many authors.

We have, based on the knowledge of the usual presence of a stenosis below a urethral diverticula, associated with the usual poor healing possibilities, adopted the technique described by Monseur (1968), mainly used for urethral stenosis by fixation of the upper part of the urethra, corresponding to its stenosed portion, to the subcavernosal groove. Instead of splitting the superior part of the urethra, we excise the additional lesion, i.e. the fistula or the diverticulum, progressively aiming the incision towards the superior part of the urethra anteriorly and posteriorly.

\section{Technique}

The incisions are those of Monseur: (a) forwards: around the balano-prepucial groove thus allowing the stripping of the skin of the penis, freeing the urethra and (b) backwards: by a sagittal incision of the perineum uncovering the posterior part of the penis urthra and its perineal part (Fig. I). The urethra is, then, separated

\footnotetext{
${ }^{1}$ Requests for offprints should be directed to Dr F. Jurascheck.
} 

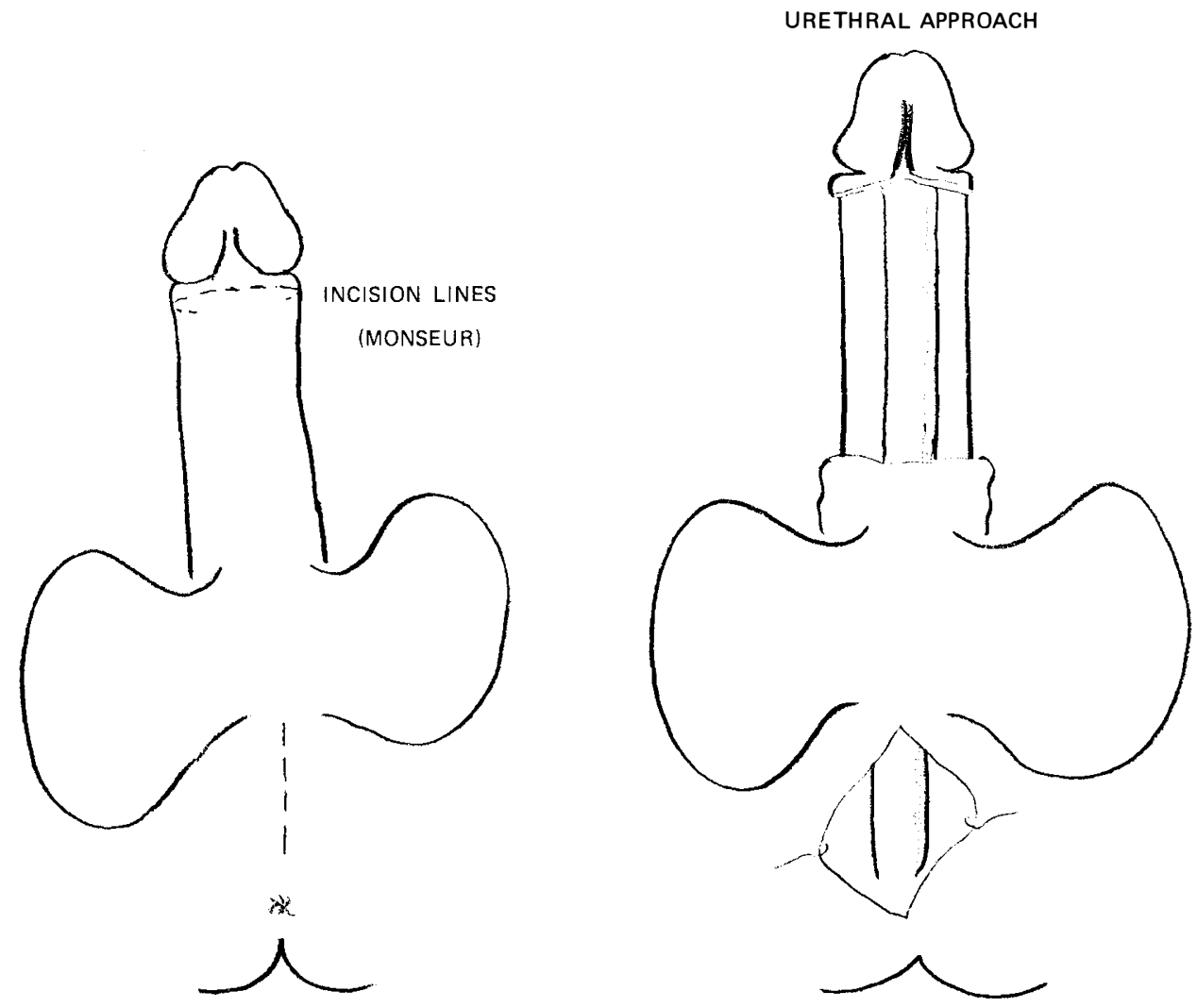

FIG. I

by section on both sides along the diseased part from its corpi cavernosi attachments (Fig. 2).

The fistula, or the diverticulum is, then, excised and, from that point, an oblique incision is performed forwards and backwards towards the median dorsal region of the urethra thus including and enlarging the stenosis area at least $2 \mathrm{~cm}$ beyond it and at least $4 \mathrm{~cm}$ posteriorly to the fistula (Fig. 3). This is important, especially when these lesions are located in the ventral part of the urethra.

The canal, thus split, is rotated in such a way that its edges can be fixed to the albuginea of the corpi cavernosi, on the right and left side of the subcavernal groove (Fig. 4), forming, in fact, a neo-urethra, as epithelialisation of the top of the urethra occurs in all cases. In this manner, we obtain an enlargement of the canal, reconstituting the urethral duct, this appearing to be irreversible because of the distances between the two urethra anchoring lines (Fig. 5).

As for the lesions situated too close to the external sphincter, these are treated by excision and ventral slipping of the two hemiroofs of the urethra following the technique of Couvelaire and Cukier (1974) but not in our spinal cord injury series reported here.

The urine is diverted by a simple supra-pubic drainage for 15 to 20 days. A modelling catheter is left in situ for no more than 48 hours. The penis is kept backwards towards the abdomen and the subcutaneous tissues are drained by two 
URETHRAL FISTULA
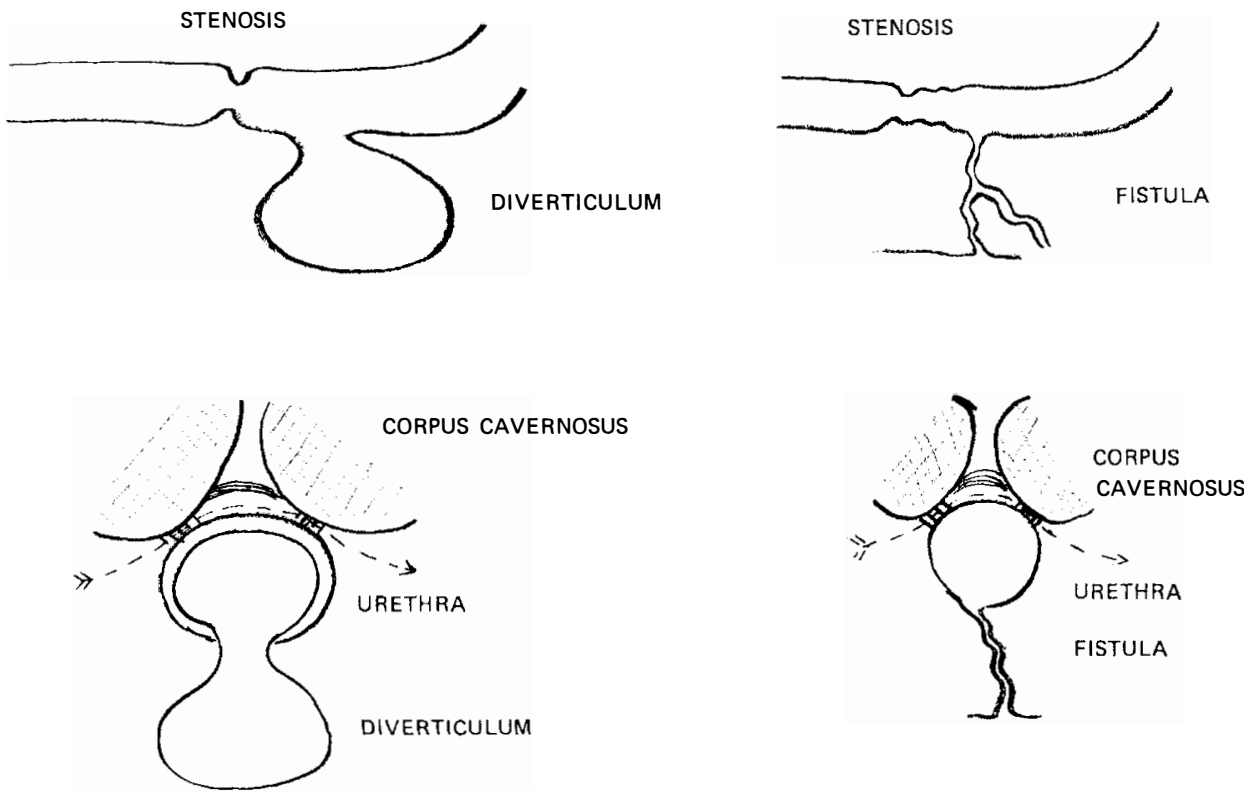

Fig. 2

URETHRAL PLASTY

AFTER SUTURE OF THE EDGES TO THE INFERIOR PART OF THE. CORPI CAVERNOSI

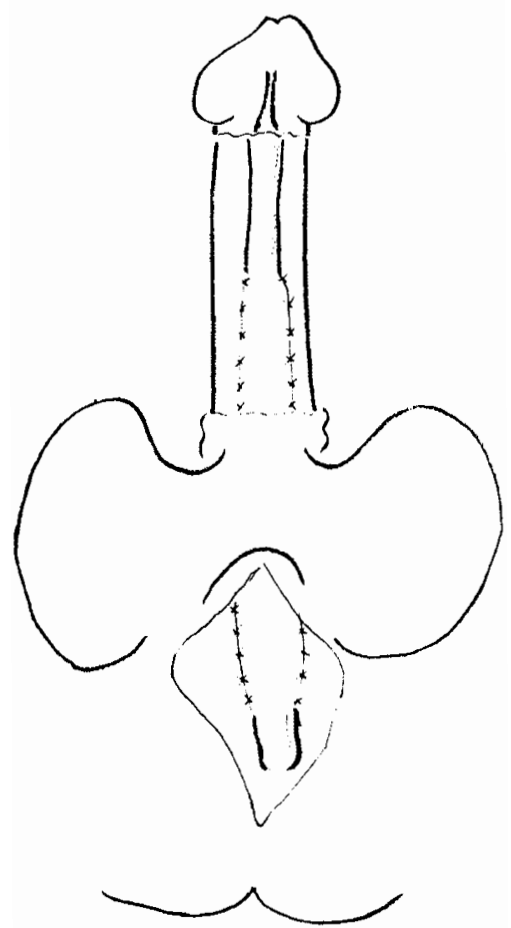

FIG. 3 
(1)

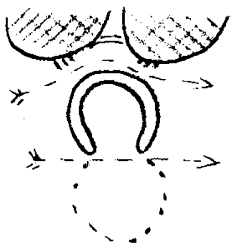

(2)

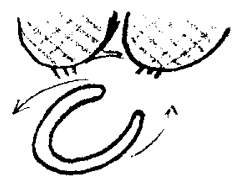

FIG. 4
(3)

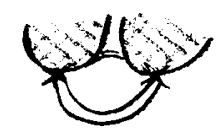

URETHRAL PLASTY

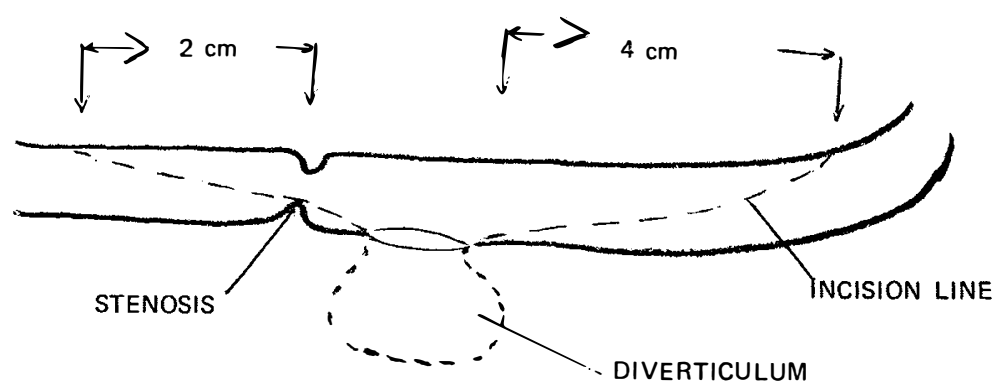

FIG. 5

small tubes connected to negative pressure. One must avoid compression, by the bandage, impeding the very important venous return in that area, also allowing the haemorrhage of the corpus spongiosus to cease spontaneously. The penis must be mobilised regularly as we did have a small area of necrosis of the prepuce by too much compression on one side, happily without sequela.

\section{Case Reports}

Case No. I: G. E. N. ... A., complete spastic lesion below T9. During the acute phase, 9 years ago, he developed a peno-scrotal abscess, necessitating a cystostomy followed by a resection of the bladder neck and external sphincter. One year after, spontaneous rupture of the sub-urethral diverticulum, leading to an abscess followed by a fistula. Two months later (1975), probably too soon, in this first case of our series, he was operated on using the above-described technique, but this was not extended enough forward and backwards, as 2 years later a new fistula occurred which was closed using the sub-epidermic Kishev technique. The canal is actually normal and largely dilated. Since the healing occurred, there has been no automatic hyperreflexia attacks, previously very disturbing for this patient.

Case No. 2: G. I. A. . . . R., incomplete lesion below $\mathrm{C}_{2}-\mathrm{C}_{3}$, by luxation of $\mathrm{CI}_{\mathrm{I}}-\mathrm{C}_{2}$ fixed by graft. He was seen I year later with a complete urinary retention. Catheterisation was impossible, due to an important stenosis. A temporary cystostomy was performed and a plastic operation according to Monseur's technique, followed after by a bladder-neck resection. Actually, this patient empties his bladder completely without difficulty, the retrograde urethro-cystogram shows a perfect permeability of the urethra in the penis. 
Case No. 3: G. I. S. . . . A., complete traumatic spinal cord lesion below T8 due to a fracture of T8 sustained II years ago. I970: resection of the external sphincter; 1971: acute appendicitis with an abcess in the Pouch of Douglas; 1975; urethral fistula after an urethrocele. After 2 months of urinary diversion by cystostomy the excision of the fistula and diverticulum was performed. These were located on the right side of the urethra. The section of the tight anterior stenosis was achieved as described previously No complications occurred and there are actually no voiding problems, micturition being triggered by a supra-pubic percussion.

Case No. 4: B. A. L. . . . C., complete lesion below L4 since 1971. First admitted 1972, then not seen until I976, when a sub-urethral diverticulum was diagnosed with a stone as well as a tight stenosis plus, further complicating matters, an intra-prostatic diverticulum. Operated with the described technique, his urethral canal heals. Voiding urethrogram shows an excellent passage with still a slight oedema between the junction between the enlarged normal canal. (This was the patient who had a small prepuce necrosis postoperatively.)

\section{Discussion and Conclusion}

All these patients were treated elsewhere by an indwelling catheter, infrequently changed, during the acute stage and after a period of months. This method of treatment demands the greatest possible care in its application. In our hands intermittent catheterisation is certainly the method of choice. None of our patients (I I 7), treated by this method, have shown such a complication.

Although applied to a very small number of patients, the aim of this paper is primarily to show the technique for spinal cord injuries. The healing of the tissues and the formation of a neo-urethra has been, until now, uneventful in three cases out of four, the first case needing a small reintervention with a good permanent result, because the plasty incision was not extended enough. More important, we think, this operation devised for spinal cord injuries, has been applied with very encouraging and lasting sucess to other patients, for instance with evolutive tuberculosis lesions of the urethra and congenital urethral defects.

\section{RÉSUMÉ}

Une nouvelle plastie de l'urètre pénienne pour fistule ou diverticule associée à une sténose de l'urètre, est décrite chez le médullaire. Quatre observations sont rapportées.

\section{ZUSAMMENFASSUNG}

Die Autoren bringen eine neue Technik für Urethrodivertikel und Urethrofisteln. Die Urethra wird vom Divertikel, bez. von der Fistel ausgeschlitzt und der eröffnete Kanal wird beiderseitz an die Corpora Cavernosa Penis genäht. Es kann sich so keine neue Kanalverängerung bilden und die Resultate erscheinen gut.

\section{REFERENCES}

Bors, E. \& Comarr, A. E. (I97I). Neurological Urology, pp. 3I4-3I8. S. Karger, Basle. Couvelaire, R. \& Cukier, J. (I974). Nouveau Traité de Technique Chirurgicale, T.XV, Urologie. Masson \& Cie, Paris, 726.

GuttmanN, L. (1973). Spinal Cord Injuries, pp. 387-392. Blackwell Scientific Publications, Oxford.

MoNSEUR, J. (I968). La reconstruction du canal de l'urètre au moyen des lames susurétrales et de la gouttière sous-caverneuse. F. Urol. \& Néphr., 755-768.

WALSH, J. J. (I964). Management, treatment, rehabilitation and complication of the paraplegic patient, pp. 84-88. Thesis of Dublin. 